\title{
West Java Regional Cultural Management UPTD in Designing Virtual Art Performances During the COVID-19 Pandemic
}

\section{UPTD Pengelolaan Kebudayaan Daerah Jawa Barat dalam Merancang Pergelaran Seni Virtual Saat Pandemi COVID-19}

\author{
Novianti Eka Kartika ${ }^{1 *}$, Dasrun Hidayat ${ }^{2}$ \\ 1,2 Fakultas Komunikasi dan Desain, Universitas Adhirajasa Reswara Sanjaya, Indonesia \\ Jl. Sekolah Internasional No.1-2 Antapani, Bandung
}

\section{OPEN ACCESS \\ ISSN 2541-2841 (online) ISSN 2302-6790 (print) \\ Edited by: Didik Hariyanto \\ ${ }^{*}$ Correspondence: Novianti Eka Kartika noviantiekak@gmail.c \\ om}

Citation:

Kartika, Novianti, E. and Hidayat, Dasrun (2021) UPTD Pengelolaan Kebudayaan Daerah Jawa Barat dalam Merancang

Pagelaran Seni Virtual saat

Pandemi COVID-19, Kanal, 9(3).

Doi:10.21070/kanal.v9i3.1570

\begin{abstract}
Virtual art performances are a form of program during the pandemic by the West Java Regional Cultural Management UPTD in the use of social media on YouTube. The purpose of this study was to determine the design of the virtual art performance program starting from the initial analysis stage, the production stage to the postproduction by the executor of the West Java Regional Cultural Management UPTD. This research uses qualitative research with ethnographic study of public relations. This study aims to examine the behavior of public relations (PR) communication carried out by virtual art performers in collaboration with artists to carry out virtual art performances. The results of this study indicate that there are stages of the virtual art performance program, starting from the stage of situation analysis, determining the goals and objectives of the program. The stages during production are holding virtual art performances and post-production such as editing and uploading to YouTube media. Therefore, this study uses the relevant model, namely The IPPAR (Insight, Strategic Program, Program Implementation, Action and Reputation) mode in the process of virtual art performances.

Keywords: Virtual Art Performances; Virtual Art Show; COVID-19.
\end{abstract}

\begin{abstract}
Abstrak
Pergelaran seni virtual merupakan bentuk program selama masa pandemi oleh UPTD Pengelolaan Kebudayaan Daerah Jawa Barat dalam pemanfaatan media sosial di youtube. Tujuan penelitian ini untuk mengetahui rancangan program pergelaran seni virtual mulai dari tahap analisis awal, tahap produksi hingga pasca produksi oleh pelaksana dari pihak UPTD Pengelolaan Kebudayaan Daerah Jawa Barat. Penelitian ini menggunakan penelitian kualitatif dengan studi etnorgrafi public relations. Studi ini bertujuan untuk perilaku komunikasi public relations (PR) yang dilakukan oleh para pelaksana pergelaran seni virtual dalam bekerja sama dengan para seniman untuk melakukan kegiatan pergelaran seni virtual. Hasil penelitian ini menunjukkan adanya tahapan-tahapan dari program kegiatan pergelaran seni virtual mulai dari tahapan an-
\end{abstract}


alisis situasi, menentukan tujuan dan sasaran program. Tahapan pada saat produksi menyelenggarakan pergelaran seni virtual dan pasca produksi seperti melakukan editing dan mengunggah ke media youtube. Maka dari itu, penelitian ini menggunakan model yang relevan yaitu mode The IPPAR (Insight, Program Strategic, Program Implementation, Action and Reputation) dalam proses tahapan program pergelaran seni virtual.

Kata Kunci: Penampilan Seni Virtual; Pagelaran Seni Virtual; COVID-19.

\section{PENDAHULUAN}

Teknologi informasi dan komunikasi yang berkembang setiap tahunnya membuat jumlah pengguna internet terus meningkat di seluruh dunia tak terkecuali di Indonesia. Pusat Kajian Komunikasi UI melakukan rilis pers tentang hasil survei profil pengguna internet di Indonesia. Hasil survei ini merupakan hasil kerja sama dengan APJII yang merupakan sumber informasi tentang data pengguna internet di Indonesia saat ini. Hasil peninjauan tersebut menunjukan pengguna internet masyarakat di Indonesia telah mencapai 88,1 juta pengguna (Atiko, et al., 2016).

Kemajuan teknologi dan adanya internet telah membuka gerbang baru bagi masyarakat untuk memperoleh informasi secara otonom. Masyarakat dapat mengakses informasi apapun yang ingin diketahui dan dimanapun mereka berada dengan media sosial. Media sosial merupakan platform media yang bersifat sangat terbuka (Suciska, 2016). Maksud terbuka yaitu khalayak luas dapat menggunakan media sosial untuk kebutuhan yang diperlukan dalam kemudahan aktifitasnya sehari-hari. Dengan keterlibatan yang tinggi, dimana pengguna dapat berinteraksi dengan pengguna lainnya, sehingga adanya komunikasi timbal balik (feedback) di media sosial secara dua arah dan real time. Pengoperasian akun media sosial oleh siapapun, meski dengan keterbatasan pengetahuan yang minim tidak menjadi halangan dalam menggunakan media sosial, karena kecanggihan teknologi dan informasi yang sangat mudah di akses oleh siapapun (Satvikadewi \& Hamim, 2016).

Media sosial menjadi suatu solusi dan informasi dari permasalahan yang ada di dunia, seperti berita tentang penyakit COVID-19 yang menyebarluas pada tahun lalu di seluruh belahan dunia. Pemerintah di Indonesia memberlakukan aturan kebijakan untuk mengatasi penyebaran COVID-19 yang semakin meluas seperti social distancing, physical distancing, Pembatasan Sosial Berskala Besar (PSBB), work from home untuk seluruh pekerja kantoran, study from home untuk para pelajar sekolah hingga perkuliahan, hingga menutup seluruh kegiatan pada sektor pariwisata (Wijayanengtias \& Claretta, 2020).

Dalam menjalalankan kebijakan pada saat COVID-19, mulai dari intansi pendidikan, lembaga pemerintahan hingga lembaga swasta melakukan cara baru untuk beradaptasi dengan peraturan yang ada. Kegiatan yang biasa dilakukan secara langsung tatap muka atau kegiatan offline, sekarang dilakukan virtual secara online. Cara baru yang dilakukan ini menjadi bentuk pemanfaatan media online di saat pandemi. Elemen kunci literasi digital yaitu melibatkan kemampuan untuk melakukan tindakan digital (Rahmania et al., 2018). Literasi digital adalah ketertarikan dan sikap dalam menggunakan teknologi digital dan alat komunikasi untuk mengakses, mengelola, mengintegrasikan, menganalisis dan mengevaluasi informasi, membangun pengetahuan baru, membuat dan berkomunikasi dengan orang yang dituju agar dapat berpartisipasi secara efektif dalam masyarakat (Wahyuni et al., 2020).

Kegiatan yang serba dilakukan secara virtual menjadi solusi di masa pandemi. Mulai dari kegiatan online meeting kantor, pendidikan, maupun kegiatan hiburan lainnya seperti kegiatan seni yang dilakukan secara virtual untuk menjaga sistem ability dan keberlanjutan kegiatan tersebut (Mayopu, 2020).

Seperti kegiatan pergeleran seni yang biasa dilakukan offline di teater Dago Tea House sekarang dilakukan secara virtual di media sosial Youtube UPTD Pengelolaan Kebudayaan Daerah Jawa Barat. Program pergeleran seni virtual di media sosial Youtube UPTD Pengelolaan Kebudayaan Daerah Jawa Barat dilakukan demi menjalankan tugas, pokok, dan fungsi di saat pandemi. Perancangan program yang sangat diperhatikan mulai dari pengemasan bentuk program dari offline menjadi online, merumuskan latar belakang program, menentukan tujuan program, merumuskan sasaran program, hingga merumuskan strategi program. Tahapan kerja tersebut selaras dengan hasil penelitian sebelumnya terkait dengan perencanaan program melalui strategi IPPAR Model meliputi Insight, Program Strategic, Program Implementation, Action and Reputation (Hidayat et al., 2017). Namun, perbedaan dari kajian ini meneliti tentang keterkaitan antara temuan pola perilaku Jakhu Suku dengan konsepsi Public Relations dan persamaannya menggunakan strategi IPPAR Model Insight, Program Strategic, Program Implementation, Action and Reputation.

Dalam penelitian ini, media yang digunakan dalam menjalankan program pergeleran seni virtual oleh UPTD Pengelolaan Kebudayaan Daerah Jawa Barat adalah media sosial Youtube. Youtube merupakan situs media digital (video) dengan fitur kemudahan untuk meng-unduh, mengunggah, serta membagikan (share) video ke seluruh penjuru 
dunia sehingga video tersebut menjadi viral (Samosir et al., 2019). Program tersebut dilakukan karena media Youtube menjadi salah satu media yang dapat menayangkan berbagai jenis seni dalam bentuk video tanpa durasi yang ditentukan. Program pergeleran seni virtual ini juga diharapkan menjadi salah satu wadah para seniman untuk tetap berkarya di saat pandemi serta membantu para seniman untuk tetap melakukan pekerjaannya yang tidak bisa dilakukan secara offline.

Penelitian ini memiliki perbedaan pada penelitian sebelumnya yang berjudul "Strategi Branding Dinas Kebudayaan dan Pariwisata Kota Malang dalam Membentuk Image Sebagai Kota Pariwisata". Hasil dari penelitian ini yaitu dalam pembentukan strategi branding kota Malang, Disbudpar melakukan perancangan mulai dari Brand Positioning, Brand Identity, Brand Personality, Brand Communication dan Brand Equity (Albet \& Dewi, 2019). Meskipun pada penelitian sebelumnya menjelaskan tentang penggunaan media sosial oleh instansi pemerintah Disbudpar kota Malang, tetapi perbedaan terletak pada cara penggunaan media sosial dan proses tahapan program. Penelitian ini menggunakan media sosial Youtube sebagai alat untuk menayangkan pergelaran seni virtual di masa pandemi COVID-19 dan perbedaan dalam merancang programnya mulai dari melakukan analisis awal untuk menentukan tujuan dan sasaran, melakukan tahapan produksi hingga pasca produksi program pergelaran seni virtual.

Berdasarkan pemaparan pada bagian latar belakang, maka penelitian ini berfokus pada "bagaimana UPTD Pengelolaan Kebudayaan Daerah Jawa Barat merancang pergelaran seni virtual saat pandemi COVID-19?”. Penelitian ini bertujuan untuk mengetahui bagaimana pihak UPTD Pengelolaan Kebudayaan Daerah Jawa Barat melakukan aktifitas komunikasi oleh para pelaksana kegiatan pergelaran seni virtual dalam melakukan tahapan perancangan programnya dan bertujuan untuk menjalankan Tupoksi (Tugas, Pokok dan Fungsi) sesuai dengan Pergub yang berisikan, penyelenggaraan pengkajian bahan pertunjuk teknis pengelolaan kebudayaan daerah. Penyelenggaraan pengelolaan kebudayaan daerah meliputi cagar budaya dan permuseuman serta atraksi seni budaya. Manfaat dari hasil penelitian yang telah dilakukan yaitu kepada para seniman atau creator tetap dapat melakukan pentas seni di masa pandemi COVID-19, dimana pemanfaatan media sosial menjadi wadah agar mempermudah kegiatan seni yang semula dilakukan secara offline namun sekarang dilakukan secara virtual. Penelitian ini juga diharapkan dapat bermanfaat bagi pembaca untuk memberikan informasi program apa yang dilakukan pihak UPTD Pengelolaan Kebudayaan Daerah Jawa Barat pada saat pandemi.

\section{METODE PENELITIAN}

Penelitian ini fokus mengkaji "bagaiamana UPTD Pengelolaan Kebudayaan Daerah Jawa Barat merancang pergelaran seni virtual saat pandemi COVID-19?" dengan tu- juan untuk mengetahui aktifitas komunikasi oleh para pelaksana kegiatan pergelaran seni virtual dalam melakukan tahapan analisis tujuan program, sasaran program, menentukan dan merancang konten pergelaran di media youtube. Proses tahapan tersebut relevan dengan studi Etnografi Public Relations (PR). Studi Etnografi PR memiliki perbedaan dengan studi Etnogradi komunikasi, yaitu Etnografi Komunikasi memfokuskan pada pola perilaku komunikasi sebagai salah satu komponen penting dalam system kebudayaan dan pola ini berfungsi di antara konteks kebudayaan. Sedangkan studi Etnografi PR berfokus pada perilaku komunikasi PR yang membangun sebuah hubungan dengan masyarakat (Hidayat, 2016). Perilaku komunikasi dalam penelitian ini adalah bentuk aktifitas komunikasi yang dilakukan para pelaksana pergelaran dengan publiknya. Penelitian ini menggunakan pendekatan metode kualitatif, pokok pandangan yang merupakan keterkaitan dari masalah yang berhubungan dengan manusia yang secara mendasar dan menggunakan paradigma yang digunakan pada penelitian ini yaitu paradigma konstruktivistik.

\section{HASIL DAN PEMBAHASAN}

\section{Merancang Pergelaran Seni Virtual (Analisis Swot)}

Dalam perancarangan tahap pertama yang dilakukan yaitu Insight. Insight adalah awal untuk menentukan latar belakang kegiatan. Seperti yang dijabarkan di hasil penelitian, tahapan Insight pada program pergelaran seni virtual yaitu persiapan dalam menentukan tujuan dan sasaran program (Tench, 2006). Para pelaksana pergelaran virtual melakukan analisis awal untuk mengetahui kelebihan, kekurangan, peluang, ancaman, tujuan dan sasaran program. Kelebihan atau Strenghtness pada kegiatan program pergelaran seni virtual, UPTD Pengelolaan Kebudayaan Daerah Jawa Barat tetap dapat melaksanakan kegiatan seni sebagai bentuk Tupoksi atau Tugas, Pokok dan Fungsi sesuai dengan Pergub yang berisikan, penyelenggaraan pengkajian bahan pertunjuk teknis pengelolaan kebudayaan daerah. Penyelenggaraan pengelolaan kebudayaan daerah meliputi cagar budaya dan permuseuman serta atraksi seni budaya. Penyelenggaraan evaluasi dan pelaporan UPTD Pengelolaan Kebudayaan Daerah Jawa Barat dan penyelenggaraan fungsi lain sesuai dengan tugas pokok dan fungsinya pada masa pandemi COVID-19 secara online atau virtual yang biasa dilakukan secara langsung di panggung teater terbuka Dago Tea House. Pandemi COVID-19 bukan menjadi suatu halangan kegiatan seni ditiadakan, dengan adanya teknologi canggih media digital pada saat ini memudahkan kegiatan virtual dalam pengoptimalan di media sosial Youtube berbentuk video dokumentasi pergelaran.

"Kelebihannya yaitu UPTD Pengelolaan Kebudayaan Daerah Jawa Barat masih bisa melakukan tupoksi-nya untuk melaksanakan pergelaran-pergelaran seni di Jawa Barat di masa pandemi COVID-19, tidak terhambat." (Agung Kusnadi, S.Pd, pada tanggal 31/05/21 di kantor UPTD Pengelolaan Kebudayaan Daerah Jabar). 
Adapun Weakness atau kelemahan dari program pergelaran seni virtual, yaitu pengetahuan dari seniman tradisional yang kurang mengetahui teknologi dan kesulitan menyesuaikan pergelaran di depan kamera karena terbiasa melakukan pergelaran seni secara langsung di panggung. Dan masalah teknis seperti keterbatasan alat pada saat pergelaran secara virtual. Karena pelaksanaan yang dilakukan di lokasi daerah, tidak seperti diperkotaan yang mudah untuk melakukan pertunjukan atau pergelaran secara virtual. Peluang (Opportunity) pergelaran seni virtual ini untuk memberikan manfaat kepada para seniman sebagai wadah untuk tetap berkarya pada saat pandemi dan memberikan ide kepada para seniman untuk bisa beradaptasi dan dapat mengikuti perubahan jaman atau memindahkan panggung mereka dari offline ke panggung virtual. Mengikuti kecanggihan teknologi dan bagaimana cara mengelola media sosial sebagai tempat untuk berkarya. Dan sisi ancaman (Thread) yaitu pembajakan video pergelaran seni virtual oleh oknum yang tidak bertanggung jawab dan video tersebut di jual belikan yang seharusnya noncommercial.

Pada setiap program yang dijalankan memiliki tujuan, UPTD Pengelolaan Kebudayaan Daerah Jawa Barat melakukan program ini dengan tujuan agar dapat menjalankan Tupoksi-nya yaitu melakukan kegiatan pergelaran seni di saat pandemi COVID-19 yang dimana hal tersebut dilakukan secara langsung pada panggung teater, namun sekarang dilakukan secara virtual yang ditayangkan di media sosial Youtube. Serta membantu para seniman untuk melakukan pekerjaannya yang menjadi kendala pada saat pandemi dan dengan memberikan upah pada setiap pergelaran yang dilakukan.

"Sasaran utamanya ya kita seniman, agar seniman bisa manggung. Ya, tapi ketika kita keluarkan di sosial media akhirnya jadi keseluruhan lapisan masyarakat. Malah sekarang makin memperluas panggung, yang misalnya pergelaran kan cuma sekali dengan kapasitas berapa ratus orang ketika udah masuk ke sosial media atau Youtube bisa jadi ribuan." (Iwan Gunawan S.Sn.,MM, 02/08/21, percakapan online whatsapp).

Setiap program yang dijalankan memiliki target sasaran publik. Program pergelaran seni virtual oleh UPTD Pengelolaan Kebudayaan Daerah Jawa Barat memiliki tujuan sasaran khusus kepada para pecinta seni atau seniman, tetapi tidak menutup kemungkinan sasaran publik dari program ini menjadi khalayak atau masyarakat luas yang dapat dengan mudah mengakses pergelaran seni virtual ini di media sosial Youtube, karena konsumsi media sosial yang dengan mudah digunakan mulai dari kalangan remaja hingga orang tua.

\section{Menentukan Konten Pergelaran}

Tahap berikutnya adalah perencanaan. Pada tahap ini memaparkan tentang main message, jenis, bentuk dan nama program. Program Strategic merupakan upaya menempatkan perencanaan yang sesuai dengan tujuan akhir kegiatan (Tench, 2006). Penentuan konten pergelaran seni virtual seperti menjelaskan pesan utama, jenis, bentuk, nama dan isi program. Pesan utama pada program pergelaran seni virtual yaitu para seniman atau creator tetap dapat menciptakan karya seni secara produktif di masa pandemic COVID-19. Dengan adanya program ini, bisa menjadikan para seniman agar lebih kreatif dan memberikan ide untuk menyelenggarakan karya seni dalam bentuk virtual tanpa terhalang oleh keadaan pandemi. Jenis program pergelaran seni virtual ini yaitu government work oriented. Bentuk program pergelaran seni virtual berupa dokumentasi pergelaran. Dengan nama programnya yaitu "Pergelaran Seni Virtual" dengan bertemakan sesuai dengan judul dari setiap pergelaran yang di adakan dan yang diunggah di Youtube, seperti pergelaran seni unggulan, pergelaran seni kreasi baru, pergelaran seni kontemporer dan pergeleran aneka ragam seni.

\section{Merancang Media Youtube Untuk Pergelaran Virtual}

Tahapan produksi pergelaran seni virtual untuk di unggah ke media youtube. Tahapan ini merupakan output program yang akan diproduksi serta mendeskripsikan tahapan pembuatan atau produksi program (Hidayat et al., 2017). Output dari pergelaran seni virtual berbentuk video dokumentasi pergelaran dengan durasi yang beragam. Mulai dari pertunjukan musik berkisar 10 hingga 15 menit dan pergelaran cerita wayang orang berkisar 45 menit hingga 1 jam. Pergelaran seni virtual dilaksanakan dengan melakukan kerjasama antara UPTD Pengelolaan Kebudayaan Daerah Jawa Barat dengan pemerintah daerah atau otonom daerah sanggar setempat. Lokasi pergelaran atau sasaran daerah yang ditentukan oleh UPTD Pengelolaan Kebudayaan Daerah Jawa Barat menyesuaikan dengan data lokasi yang telah dianalisis sebelumnya agar tempat daerah dapat terealisasikan sama rata. Pemilihan talent, hingga ide atau gagasan dari setiap cerita pergelaran ditentukan oleh pemerintah daerah dengan menunjuk sanggar yang telah dipilih. Hingga tahap editing dari video tidak melakukan banyak perubahan sehingga tetap menjaga hasil murni pergelaran tersebut dimana sesuai dengan bentuk programnya yaitu dokumentasi pergelaran.

"Jadi, kita tuh kerjasama dengan pemerintah daerah untuk izin melakukan pergelaran seni virtual. pihak kita mengirimkan surat kepada pemerintah daerah setempat. Kalau sudah deal dan oke, mereka akan menyediakan sanggar dan seniman untuk pertunjukan seni ini. untuk tahapan produksi itu semua sudah menjadi tugas dan kreatifitas dari para seniman, kami hanya sebagai penyedia atau medianya. Kami datang ke tempat sanggar mereka dan kami rekam pergelaran tersebut." (Edi Miharja, 04/08/21 di kantor UPTD Pengelolaan Kebudayaan Daerah Jabar)

Pendapat di atas dapat dianalisa menggunakan Teori New Media, yang merupakan sebuah teori yang dikembangkan oleh Pierre Levy, yang mengemukakan bahwa media baru me- 
rupakan teori yang membahas mengenai perkembangan media. Dalam teori new media, terdapat dua pandangan, Pertama yaitu pandangan interaksi sosial, yang membedakan media menurut kedekatannya dengan interaksi tatap muka. Pierre Levy memandang world wide web (www) sebagai sebuah lingkungan informasi yang terbuka. Fleksibel dan dinamis yang memungkinkan manusia mengembangkan orientasi pengetahuan yang baru. Pandangan kedua yaitu pandangan integrasi sosial, yang merupakan gambaran media bukan dalam bentuk informasi, interaksi, atau penyebarannya, tetapi dalam bentuk ritual, atau bagaimana manusia menggunakan media sebagai cara menciptakan masyarakat. Media bukan hanya sebuah instrumen informasi atau cara untuk mencapai ketertarikan diri, tetapi menyuguhkan kita dalam beberapa bentuk masyarakat dan memberi kita rasa saling memiliki (Solomon, 2011).

\section{KESIMPULAN}

Analisis awal yaitu menentukan tujuan dan sasaran dari pergelaran seni virtual yang merupakan rancangan awal yang dilakukan oleh UPTD Pengelolaan Kebudayaan Daerah Jawa Barat. Mulai dari mengetahui sisi Streghtness (Kelebihan) dimana tetap dapat menjalankan Tupoksi (Tugas, Pokok dan Fungsi), sisi Weakness (Kelemahan) mulai dari seniman yang kurang memahami sistem pergelaran virtual serta keterbatasan alat atau teknis, Opportunity (Peluang) merupakan peluang untuk para creator di luar sana bahwa pergelaran virtual dan pemanfataan media sosial merupakan wadah untuk tetap berkarya, Thread (Ancaman) yaitu pembajakan dari oknum yang tidak bertanggung jawab, seperti melakukan jual beli terhadap video atau karya milik para seniman. Tahap kedua perencanaan konten seperti, menentukan isi pesan utama, bentuk program, tema program dan nama program. Tahap ketiga implementasi merupakan output program mulai dari pra-produksi hingga pascaproduksi dengan mendeskripsikan tahapan pembuatan atau produksi program mulai dari menjelaskan ide dan gagasan, penentuan lokasi, penentuan talent, dan lainnya pada program pergelaran seni virtual.

\section{UCAPAN TERIMAKASIH}

Penelitian ini tentu didukung oleh orang-orang yang penting bagi peneliti. Maka dari itu peneliti mengucapkan terima kasih kepada kedua orang dua yang senantiasa selalu membantu peneliti dalam melakukan penelitiannya berupa dukungan moril dan materil. Kepada Bapak Dasrun Hidayat sebagai partner dalam melakukan penelitian ini hingga selesai. Kepada temanteman seperjuangan yang tidak bisa peneliti sebutkan namanya satu persatu. Dan terima kasih juga disampaikan kepada redaksi Kanal: Jurnal Ilmu Komunikasi yang telah bersedia memuat artikel ini.

\section{REFERENSI}

Albet, P., \& Dewi, S. I. (2019). Strategi Branding Dinas Kebudayaan dan Pariwisata Kota Malang dalam Membentuk Image Sebagai Kota Pariwisata Jurnal Komunikasi Nusantara. 1(2), 107-115.
Atiko, G., Sudrajat, R. H., \& Kharisma. (2016). ANALISIS STRATEGI PROMOSI PARIWISATA MELALUI MEDIA SOSIAL OLEH KEMENTERIAN PARIWISATA RI (STUDI DESKRIPTIF PADA AKUN INSTAGRAM @INDTRAVEL).

Hidayat, D. (2016). ETNOGRAFI PUBLIC RELATIONS (Tantangan Metodologi Pada Kajian Public Relations Berbasis Budaya). 76-87.

Hidayat, D., Kuswarno, E., \& Zubair, F. (2017). THE IPPAR Model sebagai Komponen Etnografi PR pada Kajian Public Relations Berbasis Budaya. 15(April), 60-72.

Mayopu, R. G. (2020). Optimalisasi Instagram Sebagai Alat Cyber Public Relations PT . GI di Era. 5-14.

Rahmania, F. D., Soetjipto, B. E., \& Rahayu, W. P. (2018). Online Marketing Using Social Media Performed by Star-Up Entrepreneurs in Kediri Regency. 641-647.

Samosir, F. T., Pitasari, D. N., Purwaka, \& Tjahjono, P. E. (2019). Efektivitas Youtube sebagai Media Pembelajaran Mahasiswa (Studi Di Fakultas FISIP Universitas Bengkulu). 4(2), 81-91.

Satvikadewi, P., \& Hamim. (2016). PEMANFAATAN MEDIA SOSIAL SEBAGAI STRATEGI KOMUNIKASI UNTUK. 102-120.

Solomon, M. R. (2011). Consumer Behavior (Buying, Having, and Being). New Jersey: Pearson.

Suciska, W. (2016). OPTIMALISASI PENERAPAN E-GOVERNMENT MELALUI MEDIA SOSIAL DALAM MEWUJUDKAN GOOD GOVERNANCE. 374-389.

Tench, Y. (2006). Exploring Public Relations. England: Person Education.

Wahyuni, S., Harianto, E., \& Batubara, S. (2020). OPTIMALISASI APLIKASI MEDIA SOSIAL DALAM MENDUKUNG PROMOSI WISATA GEOL DESA PEMATANG SERAI. 3(2), 129-134.

Wijayanengtias, M., \& Claretta, D. (2020). Student Perceptions of Online Learning During the Covid-19 Pandemic. Kanal: Jurnal Ilmu Komunikasi, 9(1), 16-21. https://doi.org/10.21070/kanal.v9i1.685.

Conflict of Interest Statement: The authors declare that the research was conducted in the absence of any commercial or financial relationships that could be construed as a potential conflict of interest.

Copyright $\odot 2021$ Kartika and Hidayat. This is an open-access article distributed under the terms of the Creative Commons Attribution License (CC BY). The use, distribution or reproduction in other forums is permitted, provided the original author(s) and the copyright owner(s) are credited and that the original publication in this journal is cited, in accordance with accepted academic practice. No use, distribution or reproduction is permitted which does not comply with these terms. 